\title{
CO-ORDINATION AND PUBLIC ADMINISTRATION IN A GLOBAL ECONOMY - A HUNGARIAN POINT OF VIEW*
}

\author{
ATTILA CHIKÁN \\ full professor, Institute of Business Economics, Corvinus University of Budapest, Fövám tér 8, \\ H-1092 Budapest, Hungary.E-mail: attila.chikan@uni-corvinus.hu
}

\begin{abstract}
The purpose of social co-ordination mechanisms is to co-ordinate the activities of individuals and organisations specialised in the distribution of work. The paper reviews five basic types of mechanisms: market, bureaucratic, ethical, aggressive and co-operative co-ordination. Today's world operates on the basis of a duality: international cooperation is based on nation states, in which the public administrations work according to bureaucratic coordination. However, the increasingly globalized market responds to the logic of market coordination. The article argues that in terms of understanding the working of public administration, the various coordination mechanisms are of crucial importance, especially where various mechanisms meet, such as the relationship between nation states and multinational corporations.
\end{abstract}

Keywords: co-ordination mechanisms, public administration, Hungary

Journal of Economic Literature (JEL) code: ??????????

\section{INTRODUCTION}

The economic events of 2008 once again drew attention to the deep theoretical problems that have recurred more or less intensively in relation to the regulatory and operational mechanisms of the world economy for years. The financial crisis, followed by the economic crisis, has triggered loud cries of pain all over the

* This study is a revised version of a chapter of my Article "Social Co-ordination Mechanisms and the Public Sector" published in the issue of Pénzügyi Szemle (Financial Review) 2007/3-4, which is published here with the permission of Pénzügyi Szemle. 
world, while we can hear diversified opinions about the causes of the problems and how to tackle them.

The overwhelming majority of these views are distressingly unfounded and shallow, either romantically naive, or clearly harmful, ignoring the basic knowledge accumulated in the various scientific branches that are competent in this area. Naturally, we must admit that the scientific results are not very extensive either, which is understandable, because we are dealing with a new and rapidly changing phenomenon that we are only at the beginning of seriously exploring. However, there is some professional legitimacy, the veracity of which has been validated by life and experience, and about which we can say that adherence to and consideration of this professional legitimacy is of critical importance in keeping the economy on a successful course.

I think that theoretically the current crisis is a consequence of the fact that the actors (both market and public actors) did not comply with certain basic rules at all, thereby pushing this crisis to the borderline of criminality. Naturally, passing judgement on the operation of a system also involves analysing the possibility of circumventing the system and the capacity of the system to manage smaller and larger errors or even acts of crime, but we must also be aware that this is rather characteristic of how systems operate and the question is at what point will the mistake or error be attributed to the system, if its rules are not complied with. Is it the fault of the boiler when it overheats and blows up? Is it the fault of the market if certain actors step out of its framework, obviously taking advantage of the regulatory deficit? Is it the short-sightedness, lack of knowledge and natural greediness of its citizens? Is it the fault of the state if its leaders, giving into short-term political and economic policy interests, close their eyes to the phenomena that should be managed with prudent regulations because of favourable impacts on the budget, exchange rate or anything else?

These are big questions without easy answers. One thing is certain though: any hysterical swing is unfavourable. It is at least risky to talk about the end of globalisation, or the 'new economy', or the importance once again of a radical increase in the state's role (for the second time within a decade after the IT revolution). Let us think about it again: would the current crisis have occurred if 'everybody had acted according to the rules', if business people had not only been driven by making a quick profit and if the vision of state leaders had not been blurred by looking merely at favourable growth indicators? Certainly it would not have occurred. At the same time, we know that such enduring and massive 'slippage' is not the fault of individuals, but lies with the system. Without overstating the case, the system must be re-examined from various standpoints and in compliance with rigorous professional demands. 
It is in this spirit that I publish my study as the revised version of Chapter III of my study "Social Co-ordination Mechanisms and the Public Sector" (published in Pénzügyi Szemle 2007/3-4) that was prepared within the framework of a research in co-operation with and financed by the Development and Methodology Institute of the State Audit Office under the research programme 'In competition with world' of the Corvinus University's Competitiveness Research Centre.

I concluded the above-mentioned study by saying that "in the course of our research to date we have met with a lot more questions than answers'. This situation has not changed. The following study looks at only a sample of the problems outlined in the previous paragraph, without drawing any conclusions at the end. However, I do hope that this study serves to stimulate the sort of rigorous thinking that I referred to earlier and what is desirable. I would like to underline that the intention of this study is not to react directly to the issues brought to the surface by the current crises, but rather to identify underlying correlations.

\section{SOCIAL CO-ORDINATION MECHANISMS}

The purpose of social co-ordination mechanisms is to co-ordinate the activities of individuals and organisations specialised in the distribution of work. We have known since Adam Smith (1776) that specialisation increases the efficiency of certain actors of the economy (and society) in their operation within their own respective specialised field. However, apart from the efficiency of the individual actors, in order to make individual organisations (and the entire society) efficient, we must also achieve a situation in which individual behaviour (and consequent performance) and their correlations lead to a situation desirable for the society.

Several mechanisms and procedures can be used for co-ordination. We shall review five basic types of mechanisms: apart from the four mechanisms stated by János Kornai (1983) (market, bureaucratic, ethical and aggressive co-ordination) we shall also review the co-ordination mechanism which is based on the agreed co-operation of the actors, and described as co-operative transactions by the Dutch Planning Office (Kovács 2005). This addition is necessary because of the objective of this current research and because the co-ordination mechanism plays a very unique role in the relationship between the public administration and other actors of the economy. A detailed analysis of the co-ordination mechanisms described above is not included in the subject matter of our study, as it can be found in the referred sources; we have confined ourselves in this study to giving only a short description. 


\subsection{Essence of the various co-ordination mechanisms}

Market co-ordination is based on horizontal relations and an agreement between equal parties. The market price, resulting from a mutual agreement (bargaining) of the parties plays the regulatory role. The subjects of the co-ordination are customers and sellers. The latter offer the result of their (specialised) activities to customers in exchange for the payment of the established market price.

In bureaucratic (organisational) co-ordination the exchange of activities takes place upon the instruction of the actor (co-ordinator) who is positioned higher in the bureaucratic hierarchy. There is a subordination-based relationship between the parties, and regulation is achieved through instructions.

In ethical co-ordination equal parties co-operate with each other voluntarily: the relations here are rarely monetised, and co-ordination is aimed at the exchange of activities based on certain (mutually acceptable) values and social norms.

Co-operative transactions represent a transition between market and bureaucratic co-ordination, as market actors define business-type relations between the market actors and public institutions supervising them in accordance with the principles of bureaucratic regulations. These relations are regulated in a special way, involving elements of market and bureaucratic co-ordination.

Aggressive co-ordination takes place in subordination-type relationships based on dominant power: the stronger party's will is executed. This is generally applied (without a legitimate background) if none of the four mechanisms indicated above operate, i.e., the purpose of the aggressive mechanism is to fill a co-ordination vacuum.

The co-ordination mechanisms summarised above were originally interpreted in the framework of a national state. However, nowadays globalisation calls for the expansion of this framework, because co-ordination exceeds the national framework in many aspects: let us just think of the role of multinational companies in market co-ordination, or the fact that in the WTO, for example, EU Member States can no longer negotiate directly, but only through the EU (the platform for bureaucratic co-ordination has changed), or consider the turned off Russian gas valves, which is an example of international aggressive co-ordination. Consequently, the social co-ordination mechanisms may also need to be discussed within an international, global framework.

\subsection{Globalisation and co-ordination mechanisms}

On the basis of the logic of Chikán's article (2002) and the EU Commission document (Commission on Global Governance 1995) let us consider why a global 
economy has developed and why we are now up to our necks in the process of economic globalisation. In the current phase of human history the dominant capitalist economic structure is focused on capital, forming the central part of economic operation. Based on its nature, the unending objective of capital is to position itself optimally between potential investments (according to the basic laws of economics this occurs if all components of capital are equally effective). In order to achieve this, and also considering its need to adjust to perpetually changing conditions, capital requires a great deal of mobility. Capital seeks to avoid anything that hinders its mobility, including country borders. This may call for cross-border co-ordination mechanisms that operate essentially on the same theoretical basis that is applied to national co-ordination.

To date, the issue of global co-ordination has been based on the logic of bureaucratic co-ordination. Since the $19^{\text {th }}$ century nation states have primarily applied this logic as they created international organisations on the basis of similar political reasoning, and continued co-ordination activities within their own competence. Naturally, there were also various market and economic aspects reflected in this bureaucratic-political setting, but as external factors. However, the internationalisation and, ultimately, globalisation of market co-ordination means a doubling of the operational logic of the world and co-ordination focusing on global matters. The main actors based on nation states and bureaucratic co-ordination are the vote- maximising politicians, whose operational logic is fundamentally different from the main actors of the other branch, market co-ordination, i.e., from the profit-maximising business men who (forming an organisational background with multi/transnational companies) try to control the operation of society based on economic and business reasoning.

Today's world operates on the basis of this duality. Nobody knows how far the situation will develop: it is an absolutely new phenomenon in any historical comparison. However, it is certain that the dominance of politics (and bureaucratic co-ordination) experienced for centuries in the management of international issues has been shaken and today it would be difficult to say which of the two co-ordination mechanisms actually leads the world. This issue came to the focus again in relation to the crisis of 2008 , bringing up the issue of what proportionality is desirable in terms of the influence of the two co-ordination mechanisms.

It is still an open question whether this doubled operational logic will lead the development of mankind in the right direction or not. One thing is certain: we cannot be very proud of the logic of a nation states or the bureaucratic co-ordination stemming from it, which has dominated the world with increasingly more sophisticated institutions for the last 150-200 years. Naturally, a lot of good things have happened in the spirit and within the framework of this structure: school systems have been established, international culture and knowledge have developed, so- 
cial and health services have been extended, and we could continue the list. However, apart from the fact that the current efficiency of the positive developments indicated above is often questioned, the same nation state logic - as reflected in past and current wars aiming at occupation or extending influence - was used in the development of the various forms of oppressing nationalities and minorities and the restriction of basic human rights. I do not think that the growth of market co-ordination as experienced in the previous fifty years could on its own neutralise or solve these problems; nevertheless, by positioning these issues on a different level in many aspects, we can at least seek new solutions to them.

The development of the institutions of globalisation in this dual operational logic is a very interesting issue for our study. Naturally, the main actors are nation states on the one side and multinational companies on the other. It is a unique and important state of affairs that to date the institutions established for the globalisation of bureaucratic and market co-ordination have been created by nation states in accordance with the rules of political logic. The international organisation of multinational companies at the institutional level has still not taken place. There are initiatives for contracts: some corporate groups and strategic alliances exist that dominate one sector (or a region). However, these institutions are not poised for market co-ordination; on the contrary, as they contain quite a lot of components of restrictive competition they are often anti-competitive. Co-ordination based on the activity of the business sector has not been 'invented' yet - it is a question whether such co-ordination can be invented at all. At any rate, these days international organisations created by states seek to also regulate market co-ordination: I experienced the dramatic effects of the WTO Meeting held in Seattle in December 1999 and during the preparatory meetings, in which I was an active participant. The IMF and the World Bank, intending to influence the monetary regulations of the world economy (and also fiscal policies to a considerable extent), also operate much more according to political than to economic logic - not to mention the economic organisations of the UN. It doesn't take a lot of courage to admit that these organisations do not represent a suitable framework for resolving the contradictions of political and economic logic, as clearly indicated by their increasingly obvious operational problems. This should be a cause for reflection for those who see the way out of the current crisis in unilaterally increasing the economic importance of the nation states - as can often be heard nowadays.

Those international organisations that help establish a personal contact between managers have a very special role, one which can only become more important in the future. International trade organisations could be mentioned as a form of framework, as they do not only exchange views on professional, ethical and organisational issues in a particular area, but they also play a determinant norm-setting role both directly and indirectly. On the basis of my personal experience I can 
state that, in a historical comparison, these international trade organisations are moving at high speed towards the regulation of the business sector. These organisations do not make business or regulatory decisions directly, yet the strong inclination of their members to co-operate, the low risk of conflict between them, and their accumulative and applied professional skills represent a significant strength in forming behaviour.

The appearance of institutions in the civic sphere is a very important element in the shaping of co-ordination. Usually these institutions are dissatisfied with both types (market and bureaucratic) of co-ordination, i.e., the market and the role of the state, or with multinational companies and the political state. These organisations form rather heterogeneous structures, including representatives of environmental protection organisations, groups supporting the poor, trade union-type interest groups and various sophisticated intellectual groups. The increasing activities and globalisation of these organisations have been phenomena of the last ten or twenty years, definitely bringing a new colour to the management of economic co-ordination. The 'Seattle Battle' mentioned earlier, was the first major collision between regulating global organisations and civil organisations of global importance, and was soon followed by the Davos and the Prague 'battles'. Since then the involvement of NGOs in global co-ordination has continuously been on the agenda. As demonstrations effectively prevented the start of the WTO Meeting in Seattle, the other members of the Hungarian delegation and I spent most of the day talking to the demonstrators. Therefore, on the basis of my own experience I can say that these people were for the most part expressing intelligent ideas with their far-reaching demands, calling the WTO to account for the damages caused by the cutting of forests in Canada, or calling for a solution to human rights problems in China. These demonstrators had one thing in common, namely, that they hardly knew anything about the WTO against which they were demonstrating. Thus the roots of the global organisational co-operation between the various groups were absolutely clear and intelligible, but there was, at least for the time being, no common objective which could be represented not only against something (the existing institutions) but for something. Inasmuch as I consider the non-governmental sector to be the carrier of ethical co-ordination in many aspects (and I think I am not alone in this), I definitely think that this phenomenon is worth noting and that the role of these organisations in terms of global co-ordination will increase.

\subsection{New impacts of global development in our days}

Kobrin (2003) asked a question in his work as to whether or not the new developments of globalisation will lead to the obsolescence of the nation state. He identi- 
fies five main trends in the current globalisation process which are related to the above-asked question - which in my opinion is the key question of global co-ordination. The question sounded different in 2003 than it sounds today, when a lot of opinion-shaping forums took place on the expanding role of the state. Below, I shall try to express an unbiased opinion on the basis of the trends indicated by Kobrin.

\section{a) Deeper integration}

Internationalisation is best reflected in production: the national character has been rendered inconsequential by means of the production activities of multinational companies (MNCs), and it is practically impossible to 'separate' the products of many MNCs in terms of their origin or the share that a particular country has in its production. (I would like to add that the same could be said not only about traditional production, i.e., production of durable goods, but also about the majority of services. Think for a moment about financial, consultancy, IT or travel services, for example.) This suggests that the influence of a nation state on the production and service processes is an illusion - which means that political and economic emphasis has shifted from trade to investment; i.e., a shift has taken place from the public efforts for the regulation of trade to the regulation of the general economic environment, and the assessment of national competitiveness has shifted from comparative advantages (and the widely interpreted resource-based competitiveness) to investment-based competitiveness (not to mention innovation-based competitiveness, which has become a basic factor in acceptable international competitiveness today).

The consumption of resources was controlled more or less in a national framework, but the sovereignty of a state was strongly limited in the development of the regulatory environment. One may raise objections because multinationals are able to 'evade' the scope of state regulations, but the truth is that they were never included in them: they are at least equal negotiating partners of the public institutions in the establishment of the local regulations of their own operation. Naturally, in theory individual nation states have the opportunity to restrict the activities of MNCs on their own national territory, but these efforts would soon lead to catastrophic effects on the economy of the country, especially if it is a smaller country. It is not accidental that (in spite of much rhetoric to the contrary) there is in reality no such tendency, and what you find instead is that there is increasing competition in attracting MNCs.

Although the spread of multinational companies is the means which has the biggest impact on the integration of the global economy, it is not the only means. 
There are numerous signs indicating that, if the conditions are ripe, the cross-border activities of small- and medium-sized enterprises could also be important. This phenomenon falls under the scope of regionalisation and state regulations (e.g., within the EU framework) can play a very important role in the extension of integration.

\section{b) Technological development}

In many sectors (telecommunications, biotechnology, pharmaceutical sector, electronics, space research) even the largest national markets cannot generate a return on their huge $\mathrm{R}+\mathrm{D}$ expenditures. Companies operating in these sectors definitely need international (even global) markets in order to operate at a volume and with the diversity that can generate a return. Thus national markets cannot play the role of the basic economic unit of state operation to the same degree as formerly, and national markets cannot be used as the instruments of state influence over the economic actors. The breakdown of global markets into 'national' entities results in a considerable loss of its importance (for example, investors at least consider building their portfolio in terms of regional entities, within which the selection of a specific country is of secondary importance for them). Consequently, national markets are not 'concentrated' across borders; rather, this is much more like a fusion or merger. In the thinking of MNCs, the borders of 'markets' and 'states' are not the same.

Another aspect of the above concept is that national states are increasingly dependent on MNCs in terms of technical and technological development. Countries that aggressively seek to limit the role of multinational companies will face a basic competitive disadvantage.

\section{c) Networks and alliances}

The increasingly complicated distribution of work resulting from technological development called for the supplementation or occasional replacement of the traditional hierarchical MNC organisation with networks, where often there are no ownership relations between the various elements of a network. This has led to the establishment of a complex network of economic transactions, in which bilateral (buyer-seller, supplier-processor) economic relations were replaced by a diversified system of mutual dependencies. This also changed the relationship of MNCs and the governments of national states: while a traditional multinational company naturally has a specific head office operating in a particular country, it is very dif- 
ficult or nearly impossible to identify such a central head office for the strategic alliances and knowledge-based networks that are forming these days. Often owners do not have an important role in the establishment and operation of the relationships; rather, because they have the flexibility to change, their function is often more characteristic of a project. Which national state regulates the many entities involved in these networks operating on the territories of many countries? These networks cannot be drawn into the scope of national legislation or the application of law, and in respect of geography, the territory of the country where they operate is very rarely a critical element for the networks. Their location is decided only on the basis of economic considerations of the MNC: the economic and legal environment of a particular national state is either favourable for them - in which case they set up operations - or it is not favourable, in which case they move on. Numerous multinational companies operate (at least partially) as actual virtual companies, as the organisers of a large number of sub-contractors. The question is to what extent the regulations of any nation state can influence the behaviour of such a diversified network even in areas that are traditionally governed by the national legislation, such as working conditions or environmental protection.

\section{d) Multinational companies, other international actors, the global civil society}

These days the number of international organisations has increased significantly, of which the international company, although of fundamental importance, is only one. As I have indicated, in part of these international organisations (which are still essential organisations) the main role is played by the nation states and the governments thereof, including the UN and its specialised agencies, OPEC or the OECD. However, even in the traditional framework there existed international organisations (prominently, for example, the world churches) which were not under state influence, or only to a limited extent. However, with the establishment of the Internet and the World Wide Web the number and importance of formal and information organisations over the importance of nations is increasing at a dramatic speed. Amnesty International or Greenpeace are good examples of formal organisations, while theoretical and various other relational networks, organised in informal networks, such as terrorist networks, cybersex followers, horse race betting offices, or artefact collectors, are almost unidentifiable. It is very important to consider that on the one hand, these relationships often also represent economic forms and therefore they bring new challenges to the regulatory efforts of the states, and on the other hand, in this aspect MNCs represent only one part of the relatively independent international organisations (even if they are the most important ones these days). The diversity of the international relational network con- 
tinues to further dilute the importance of national borders, the distinction of "national' and 'international' concepts, and the influence of the state as merely based on economic considerations.

\section{e) Multinational companies and cyberspace}

MNCs are increasingly using the opportunities of the World Wide Web, even if electronic trade and business practices are not spreading as fast as many had projected they would when they were first introduced. Electronic business puts further limitations on the possibilities of national influence. As long as software was exchanged on disks or in manuals, the trade in software could be monitored. Nowadays, when software is downloaded from the Internet, such monitoring is virtually impossible. As long as Hungarian programmers went to Germany to produce software, the process could be followed. However, when software is produced in Hungary for a computer programme that is operated in Germany, then where is the economic value created? Where does the transaction take place, in which country? How should this transaction be regulated, by the German or the Hungarian laws? How should the performance and the income generated from it be taxed? Will any national organisation even know that the transaction took place? These questions are very difficult to answer and if we attempt to apply a national framework to them, we will inevitably limit the effectiveness of these virtual transactions, thereby automatically creating a need to bypass the regulations.

The World Wide Web makes the issue of physical location redundant. MNCs can no longer be threatened by restrictions of location or physical presence. Geographical and regulatory places are separated from each other: there is no necessary relationship between the website and the physical location. This often brings up the question as to whether or not the national law still has relevance in a particular issue or not.

\subsection{Conclusions: multinational companies and national states}

Important conclusions can be drawn from the thoughts outlined by Kobrin (2003) and commented on by me with regard to the relationship between multinational companies and national states, and their governments.

The most important conclusion is that with the spread of globalisation and MNCs, the role of nation states will not cease, but it will change fundamentally. Globalisation has weakened geographical sovereignty to such an extent that it is no longer possible to talk about legislation on a geographical basis or the priority 
of the application of law to the same degree as before. The states and their governments are no longer such major actors in the economy as they were in the $19^{\text {th }}$ $20^{\text {th }}$ centuries, but of course, they are still very important factors in the control of processes, the allocation of resources and generally the exercise of power. Globalisation has changed the rules of the game applicable to the production of goods and services and as a result the mechanisms of the regulation of operation and allocation of the generated income. The networks of the world economy cannot be controlled with traditional or other instruments generated from traditional sources by the national governments or their international organisations. The economic and political fields have been torn apart. Markets are larger than individual countries, and the national character of economic systems and actors has lost its importance in a dramatic way. Thus, nation states have lost their uniqueness in international politics as MNCs and other international organisations have become partners of equal rank with nation states in the control of the economy and indeed in some countries, in the directing of their economies.

There is a considerable interest in making politicians accept this phenomenon and restructure their policies accordingly. The countries in which this restructuring takes place faster will be the successful ones. Resigning from power is always difficult, but exercising false power is even more difficult because it leads to distortion, loss of efficiency, reduction of competitiveness and, ultimately, to lagging behind.

However, it would be a serious mistake to think that this change of roles means that nation states and national governments are no longer important. This will not happen, at least not within the foreseeable future. The government of a nation state (and generally its public administration) will continue to play a critical role in the control and co-ordination of activities in society. For me, this is true at the 'textbook' level (see Chikán 2008). The rightly posed question is how the co-ordination mechanisms based on a different logic will be able to co-ordinate and how the specific nation states, governments and administrative structures will be able to adapt not only to the requirements of globalisation, but also influence its development through their active roles. The globalisation of the economy is an historical necessity, but its actual implementation may and must be influenced by the instruments of a state. It is not accidental that among the leading economic schools (which, by the way, are usually more colourful than generally illustrated by journalists), the schools of institutional economics are those which clearly attribute the success of the whole economy as well as of individual enterprises to what is accurately expressed in the slogan: 'institutions matter', i.e., institutions have an enormously influential role (Acemoglu 2007; Williamson 1985).

Consequently, political reconsideration of the new world trends must necessarily lead us to a new role of public administration. The more political consider- 
ations impede the administrative changes stemming from global economic development, the more severe the consequent damage will be. It seems that in Hungary politicians do not think of the processes described above at all. Any restructuring at the government level relates to petty party politics and personal interests instead of linkages to global challenges. Regionality, as the local reflection of the global economy that is now becoming more important, will continue to be distorted as long as the entire administration is shaped by local (based on a specific constellation of party politics) political considerations and not by global criteria. The role of public administration is not only decreasing, it is changing with new focuses. It is facing more and more complicated issues, its monopoly position is disappearing in many aspects, and more negotiations will be needed. This concept is clearly supported by the current economic situation and its social consequences.

\section{GLOBALISATION AND PUBLIC ADMINISTRATION}

In the age of globalisation some characteristics of national public administration clearly strengthen, others clearly weaken its situation or influence.

It is clearly a strengthening factor in national public administration that it has a very important mediation role in the relationship between national agencies and national co-ordination institutions of the particular country in the global co-ordination system outlined above (where market co-ordination is implemented even by organisations based on the involvement of the nation state). Effective interest groups in global organisations assume professionally strong, nationally committed individuals and institutions which are capable of understanding global processes and maintain a strong position within the national public administration. (This is why, for example, such harmful consequences have accompanied the constant changes since the political regime change in the administrative and organisational structures of Hungarian foreign trade and R\&D - two areas are of key importance, where harmony of national and global co-ordination is extremely important.) Continuity of national representation is also very important in this context - international organisations cannot deal with fluctuation induced by local (national) political battles, and it is also impossible to efficiently represent any national interests with such a back-drop. On the other hand, it is also obvious that for interest groups to be effective there should be a strong internal public administration system with institutions capable of conveying and unravelling the impulses received from international organisations (often in the form of detailed regulations).

At the same time, several factors weaken the role and situation of public administration. There is no doubt that its influence is decreasing partly because of 
the role of multinational companies, which is extremely strong in market co-ordination (often MNCs can exert more influence on the leading politicians and their decisions than on their own professional apparatus) and also because the decision-making competence of public administration may decrease within the framework established by international organisations. (It is clear that the role of the foreign trade apparatus has been reduced by the fact that public administration can now negotiate with international organisations, including the WTO, through its EU representative instead of being represented directly by a Hungarian party.

In my opinion national administration still plays a strategic role in the age of global co-ordination. In order to fulfil the role of the nation states outlined above, it is (would be) necessary to express national interests and to develop a strategy that effectively represent both global organisations and Hungarian institutions equally.

\section{GLOBAL CO-ORDINATION AND HUNGARIAN ADMINISTRATION: TWO HIGHLIGHTS}

Below we shall discuss the two subjects that, in my opinion, are of highest importance for Hungary today in the field of globalisation, administration and competitiveness.

It can hardly be disputed that our accession to the European Union is a milestone event in Hungarian history, and can be seen as the most important factor affecting the Hungarian society and economy since the regime change. Naturally, the accession affects our involvement in global co-ordination as well as co-ordination within a national framework, which will be covered in the first sub-chapter.

As was expressed earlier, one of the most important issues of overall global co-ordination is the relationship between the nation states and multinational companies. It is extremely important especially for the transition countries, including Hungary, where economic transition could take place relatively quickly mainly because of the influx of foreign capital and the presence of MNCs. The key role that MNCs play in the Hungarian economy (consider the areas of export or innovation) follows in part from the specific conditions of the transition, including mainly privatisation and the impetus from inflows of foreign capital. Due to this there is reason to examine the relationship between the national administration and multinational companies.

The next two sections focus on the administrative impacts of the EU and MNCs. 


\subsection{Impact of the EU membership on public administration - From the aspect of economic competitiveness}

There is extensive literature discussing the issues of EU administration and its Hungarian aspects. In the framework of this study I do not cover theoretical issues at all. I shall look only at the specific factors in the relationship of the EU and public administration that affect economic competitiveness the most.

On the basis of my studies and personal experience I have identified six areas of public administration which have a significant impact on economic competitiveness within the framework of EU membership. In this section I shall describe these six factors.

\section{a) Building of a national economic strategy}

In my opinion the overall problem is that there are no established institutions or practices for building a national economic strategy. During the transition period, in the course of the restructuring of the institutional system around 1990 we threw out the baby with the bathwater: with the termination of the National Planning Office we also lost our central institution responsible for the strategy of economic management. At the same time, the sudden change of economic policy almost of necessity brought along the dominance of short-term financial and political viewpoints, which we are still suffering from, because they continually overrule even the consideration of longer-term strategic aspects, never mind their implementation. There are economic concepts, but there is no strategy and its reasons and consequences can be seen in the economy and in the system of economic management.

The process of preparation of the National Development Plan and its organisational framework clearly indicate the lack of a strategic institutional system, and the uncertainty of the public administration staff and their exposure to daily politics are (not the only) consequences of this situation.

\section{b) Restructuring of government control}

Since the regime change the structure of government control has changed significantly not only whenever a new government took office, but also several times during a government cycle. The governing parties play around with such important areas as the R\&D system, foreign trade relations or the control of human resource management. These changes are more often driven by short-term political 
or personal interests than by actual conceptional issues. This organisational and personal uncertainty, with harmful knock-on effects on the entire public administration sector is harmful not only to the entire administrative sector, but also to our integration into the European Union

\section{c) Budget and public service sector reform}

It is an important question as to what extent the developing Hungarian institutional system and operational mechanisms will assist the implementation of the economic and cohesion principles of the European Union. The lack of reforms and conceptional uncertainties to date have already caused a lot of damage to the country and it would not be good to maintain an institutional system that does not comply with the development and innovation tendencies of the European Union.

\section{d) External relations}

In my opinion Hungary would need to become more active than it is today in terms of conceptualising its foreign policy and foreign trade activities in order to play a successful role in the EU. This matter also has numerous administrative and institutional aspects. I have already referred to the management of foreign trade matters; I now refer to the handling of concerns of Hungarians living across the borders as another key issue that is a sore spot in the relationship with the neighbouring countries, which could be Hungary's potential allies in numerous issues within the European Union. The lack of an adequate and stable institutional system is also a considerable, although not the most important, deficiency in this field.

\section{e) Role of the region}

It seems that Hungary does not even wish to understand the EU trends in this aspect either. Formally, we have solved the problem by creating administrative regions, but we have not taken the required steps in terms of its content elements. These days this is reflected mostly in the tension caused between the Government's allocation of funds and their regional utilisation, the economic and political consequences of which cannot be foreseen at the moment. This is one of the key economic issues affecting national competitiveness at its core. Today it is 
clear that we are suffering huge losses as victims of party political battles, which are understandable from a political point of view, but do not in any way serve the economic interests of the country.

\section{f) Compliance with the EU regulations}

It is well-known that Hungary is a country of tricksters. Just as in the 1980s it was part of official politics to 'deceive' the World Bank and the IMF with false data (the fact that we succeeded does not confirm our cleverness, but was the consequence of the World Bank's own objectives: they also wanted to believe what was said to them), now we are experimenting with the European Union. Giving the budget a face-lift, some peculiar PPP projects, the circumstances surrounding motorway construction and the group of support institutions outsourced from the Ministries create bad impressions and lead to a lack of trust in the Hungarian administration system at almost all levels of the managing and administrative apparatus of the European Union. If we look at the EU common administrative directives (Jenei 2005), there is hardly a single directive that is not be violated by the Hungarian public administration....

\subsection{Multinational companies (MNCs) and nation states: Theoretical problems and their presence in Hungary}

Kobrin (2003) identifies four connected problem categories which relate to the relationship of multinational companies and nation states or the structure of the nation state from the moment that multinational companies make their first appearance.

a) Distribution of costs and benefits related to the activities of multinational companies. This poses a problem for the individual nation states and the relations between them.

b) Competence asymmetry between the regional characteristics of state legislation and legal practice and the international network of the MNCs and their subsidiaries.

c) Legal conflicts, overlaps and gaps as well as problems of being outside a region.

d) Reduction of state control/influence over the economy and economic actors. 
The following comments can be made for the specific points:

a) This is an evergreen subject with a lot of emotional content. From political interest to simple ignorance a lot of factors lead to a situation in which a significant number of Hungarians feel that MNCs are causing damage to the national economy, as 'they take their money out of the country'. This worldwide perspective significantly affects the acceptance and treatment of MNCs (legal, economic, social) in the transition countries, and therefore is extremely important also in Hungary. Naturally, there are some fundamentally important issues in the actual practice: MNCs have a key role in the shaping and restructuring between countries of resources and capabilities (and in relation to them, power and influence). A clear and transparent administration operating in a stable system can be of significant assistance in coming up with the right answers to these questions (in addition to the political and public opinion forming intellectuals) as it can achieve real results by leading the behaviour of MNCs in favourable directions from national aspects and can also significantly influence public sentiment. There is no doubt that (mainly due to lack of experience) often we have not managed to realise the privatisation revenues we had envisioned, or have been unable to change the conditions of certain foreign investments in our favour. However, it can hardly be disputed from a professional and objective point of view that it was primarily during the period immediately after the transition that the technology and knowledge transfer implemented by the MNCs were indispensible in the establishment of the market economy and putting a halt to a transformation decline. In this case the role of the administration was regulation and consistent implementation.

b) This problem is often discussed by international literature and was also mentioned in relation to the co-ordination mechanisms. The fact that in the entire economy and especially in the events of the business world the key role is played by the multinational companies (yet the regulation of the global economy is in the hands of national states and national state organisations) involves an immanent contradiction: a confrontation of the different logic of politicians and economists. The generally heavily centralised MNCs with clearly defined supranational interests accommodate themselves to a world order (when they do so) which is based on the logic of nation states, on the power relations, agreements and compromises between nation states. Nation states cannot question the global strategy of the individual MNCs (they do not have the legal basis or economic tools for that), and MNCs are forced to thrust their local activities into the Procrustean bed of the nation state in the territory in which they intend to operate their economic entity. The resolving of conflicts arising from this asymmetry is prevented by the fundamentally different objectives and in- 
formation base. Neither party can fully and effectively implement their respective intentions against the will of the other party. Often this conflict is described as the conflict of archaic political and modern business structures. There is clearly something in this concept, but we must not forget about the regenerating role of the nation state, which was covered earlier. This is an actual conflict, which finds a different solution so to say for every case (different in form and content). The Hungarian public administration is not free of the consequences of this conflict either, and they are often handled with great difficulty. This is why we have been unable to react since the EU accession to the significant loss of revenues suffered by the Hungarian budget as a result of the unfavourable Hungarian customs conditions and rules, whereby companies that carry out EU customs clearance go to some neighbouring country instead of remaining in Hungary. Another example we could mention is the slow process for legal remedy or implementing environmental measures, as a result of which certain economic endeavours in the international network of MNCs are carried out elsewhere and not in Hungary, which has also caused a loss in revenues.

Ball (1968) proposed a long time ago, before the actual seriousness of the problem appeared, the creation of an international corporate law managed by an international organisation. We have not gotten any closer to the establishment of such a law in the nearly forty years since the publication of the article, although the WTO was established in the meantime, which (in terms of the contents of its mission) theoretically could also manage such an international agreement.

c) Any local subsidiary of any MNC has a dual identity: on the one hand, the laws and regulations of the country apply to it (and its employees) on the territory on which it operates. On the other hand, it is also subject to the instructions that are issued by the headquarters. This could be the source of numerous problems, even at the personal level: for example, the effects on the company's employees in terms of taxation and regulation must be reconciled. Here, for example, one state 'intervenes' in the internal matters of another state (indirectly), which must be regulated with agreements between the public agencies of the two (or several) countries. Competition regulation is a special problem. Separate institutional systems manage the rules of competition. It is an empirical fact that Hungarian companies from time to time do not wish to or cannot, understand that competition regulation takes place within a uniform EU system, yet they still object to its outcomes.

d) In terms of the reduction of nation state control and influence the real reason is the distribution of work and mutual dependence between the individual countries developing from the international flow of capital and trade. At the same 
time, MNCs have also become the vehicles and symbols of the reduction of the nation state's influence and implementation of an independent economic policy focusing on the interests of the country. This very often conflicted sharply with the popular idea of the 'welfare state', within the framework of which the ratio of income centralised by the state increased in most countries of the world during the last few decades - although it would appear that those arguing for the increase of state influence have not noticed this. Consequently, a necessary conflict has developed between the nation state's leadership wishing to implement its political interests and the management of the MNCs fighting for their global business objectives. Historically the dependence of the state on the business sector has increased (or if we wish to put it positively, the degree of its reliance on the business sector has increased), which has often led to a sharp conflict.

Naturally, it's not only MNCs that put restrictions on the sovereignty of a nation state. Every time a government signs an international treaty or joins an international organisation, it must make a compromise. The difference is that in such cases the partners have a similar (political) logic; this stands in contrast to the MNCs, whose business logic is different both in terms of its basis and orientation.

Even so, it is not clear that the expansion of the MNCs was in fact accompanied by a decrease in state sovereignty. Multinational companies must enter the economy, territory and legal environment of a national state, and in so doing they can also strengthen the role and importance of the nation state.

\section{CONCLUSION AND MAIN HIGHLIGHTS}

As I have summarised in the study, with regard to the relationship between social co-ordination and the public sector this is much rather the first word than a mature research product. I have found that this relationship is a fairly unexplored area, at least in respect of economics. I think I have managed to prove that the approach is promising, and perhaps has already led to a few important results. Let me briefly summarise them below.

- It is an important task to clarify the relationship between the public sector, more specifically public administration, and the various co-ordination mechanisms. Based on this, we would like to highlight the intermediary role that can be played by public administration in the harmonisation of bureaucratic and market co-ordination. This approach could be of critical importance in the management of social reform processes, the lack of which is one of the primary risk factors to the success of the current reforms. 
- The conclusion that public administration - which also mediates between international and national bureaucratic co-ordination - is the most important actor in the implementation of bureaucratic co-ordination at the level of a nation state, could lead to important research projects and practical results. In relation to the issues covered under the previous point we have found a double intermediary role for public administration, which can also serve as an Archimedes point in the control of reform processes. This interpretation of public administration provides an opportunity for the administration-based modelling of the national co-ordination mechanisms, which can lead to exciting outcomes.

- The extension of the theoretical basis of the co-ordination mechanisms to public service providers leads to important conclusions about the specificities of the triangle of politics, administration, and public service. There are many correlations in this framework both theoretically and in relation to current Hungarian developments regarding, for example, the relationship between self-reliance, state paternalism and the NGOs.

- I think it is also important to identify the historical aspects of the issue. It is of course a commonplace to say that without the past the present cannot be understood and the future cannot be influenced. However, the question of where the emphasis is or can be put in terms of social and economic reforms should be concretely defined; then the weaknesses of government action would be judged in a different light, just as would be rioting in the streets.

- The international literature only touches on the issue of global co-ordination these days. In a small open economy like the Hungarian economy, the means of the global expansion of co-ordination is a cardinal issue, because this will determine our scope of manoeuvrability. The approach based on international co-ordination mechanisms could be very productive for the establishment of a much needed foreign trade strategy (and a comprehensive strategy on foreign matters comprising foreign trade) - such a strategy must definitely align itself with global trends.

- Two highlights within the subject of global co-ordination (the relationship with the EU and multinational companies) focus attention on several key problems of Hungarian social and economic development. On a theoretical basis, these problems can be derived from the two fundamental principles of global co-ordination: deeper integration and the appearance of new actors/roles. Therefore, the dual mediation role of public administration between national and international co-ordination on the one hand, and between bureaucratic and market co-ordination on the other as indicated above, becomes extremely important, and can be contrasted in a meaningful way with the various approaches taken towards the EU and multinational companies, which are often half-baked and/or emotionally driven, but from time to time are politically very effective. 
Hopefully, the ideas above have outlined what I referred to in the introduction of the study when I urged for a thorough rethinking of the current crisis, of globalisation and the role of the state. The issues covered by the study indicate the foundational depth to which we must return. We must not give in to any momentary mood (either gloomy as at present, or potentially bright later on), we must not judge or use slogans hastily where professional arguments confirmed by the sciences and by life can be resorted to, or at least where good questions can also be raised.

\section{REFERENCES}

Acemoglu, D. (2007): Válogatás Daron Acemoglu munkáiból [Selection from the Works of Daron Acemoglu]. Budapest: Rajk László Szakkollégium - Ráday Könyvesház.

Ball, G. W. (1968): “COSMOCORP: The Importance of Being Stateless”. The Atlantic Community Quarterly 4(2): 163-170.

Chikán, A. (2002): “A gazdaság globalizációja és a civilizációk különbsége” [Globalisation of the Economy and Difference of Civilisations]. Magyar Tudomány 2002(6): 730-737.

Chikán, A. (2007): “A társadalmi koordinációs mechanizmusok és a közszféra” [Social Co-ordinations Mechanisms and the Public Sector]. Pénzügyi Szemle 52(3-4).

Chikán, A. (2008): Vállalatgazdaságtan [Business Economics]. Budapest: Aula Kiadó.

Commission on Global Governance (1995): Our Global Neighborhood. New York: Oxford University Press.

Jenei, G. (2006): Közös közigazgatási irányelvek az EU-ban [Common administration guidelines in the EU]; www.bke.hu/kkar/download/TSZ-KSZ/KozigazgatasIranyelvek_az_EU-ban.doc.

Kobrin, S. J. (2003): „Sovereignty@Bay: Globalization, Multinational Enterprise, and the International Political System". In: Rugman, A. M. - Brewer, T. L., eds: The Oxford Handbook of International Business. Oxford: Oxford University Press.

Kornai, J. (1983): "Bürokratikus és piaci koordináció" [Bureaucratic and Market Co-ordination], Közgazdasági Szemle (1983)9: 1026-1038.

Kovács, Á. (2005): „Versenyképesség és államháztartás, Alternatívák forgatókönyv-választáshoz” [Competitiveness and the Budget. Alternatives for Scenario Selection], Pénzügyi Szemle 50(1): $26-48$.

Smith, A. (1776, 1977): An Inquiry into the Nature and Causes of the Wealth of Nations. Chicago: University Of Chicago Press.

Williamson, O. (1985): The Economic Institutions of Capitalism. New York: Free Press. 